\title{
Influenza vaccine recommendations for children and youth for the 2008-2009 season
}

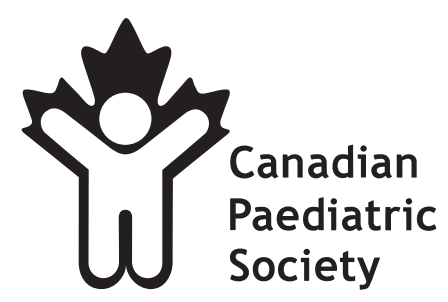
The national goal for influenza vaccination is the complications. The National Advisory Committee for Immunization (NACI) encourages influenza vaccination for all Canadians who have no contraindications, and makes annual recommendations on influenza vaccine dosages and schedules, as well as defines high-risk groups. The NACI statement also provides an update on the antigenic components of the vaccine recommended by the World Health Organization, which are based on current and emerging influenza strains. The 2008-2009 vaccine in Canada will contain World Health Organization-recommended strains A/Brisbane (H1N1)-like, A/Uruguay (H3N2) and $\mathrm{B} /$ Florida. All three components of the vaccine will be a change from the 2007-2008 version (1).

Priority is given to immunization of children and youth at high risk of influenza-related complications, and those capable of transmitting infection to individuals at high risk of complications.

\section{RECOMMENDED HIGH-PRIORITY RECIPIENTS OF KILLED INFLUENZA VACCINE (PERTINENT TO HEALTH CARE PROVIDERS$$
\text { OF CHILDREN, YOUTH AND }
$$$$
\text { PREGNANT WOMEN) }
$$

- All children six to 23 months of age;

- People providing regular care for children younger than 24 months of age;

- Members of households expecting a newborn during influenza season;

- Pregnant women; and

- Children and youth with:

- cardiac or pulmonary disorders including chronic lung disease of prematurity (bronchopulmonary dysplasia), cystic fibrosis or asthma;

- diabetes mellitus;

$\circ$ metabolic diseases;

TABLE 1

Recommended killed influenza vaccine dosage, by age, for the 2008-2009 season

\begin{tabular}{lcc}
\hline Age & Dose $(\mathbf{m L})$ & Number of doses \\
\hline 6-35 months & 0.25 & 1 or $2^{*}$ \\
3-8 years & 0.5 & 1 or $2^{*}$ \\
$\geq 9$ years & 0.5 & 1 \\
$\geq 18$ years & 0.5 & 1
\end{tabular}

*Two doses of influenza vaccine separated by at least one month is recommended for children younger than nine years of age who are receiving influenza vaccine for the first time. Adapted from reference 1

$\circ$ cancer;

$\circ$ immunodeficiency and immunosuppression;

$\circ$ renal disease;

$\circ$ anemias or hemoglobinopathies;

- conditions that compromise the management of respiratory secretions and are associated with an increased risk of aspiration;

- children and youth with conditions treated for long periods of time with acetylsalicylic acid; or

$\circ$ residents of chronic care facilities.

Both adults and children who are household contacts of individuals with high risk of complications should also be immunized to try and prevent the illness from coming into the household.

As discussed in the NACI's statement (1) for the 2008-2009 season, all previously unvaccinated children younger than nine years of age should receive two doses of killed influenza vaccine for the first year in which they are vaccinated (Table 1 ). This is particularly important for children six to 23 months of age because they are unlikely to have had previous priming exposure to the influenza virus, and they also receive a lower dose of vaccine per injection (2-5).

All health care workers who work with children and youth should themselves undergo yearly influenza vaccinations,

Correspondence: Canadian Paediatric Society, 2305 St Laurent Boulevard, Ottawa, Ontario K1G 4J8. Telephone 613-526-9397,

fax 613-526-3332, Web sites www.cps.ca, www.caringforkids.cps.ca 
unless they have an absolute contraindication. As stated by the NACI, "In the absence of contraindications, refusal of healthcare workers who have direct patient contact to be immunized against influenza implies failure in their duty of care to patients" (1).

\section{REFERENCES}

1. Statement on influenza vaccination for the 2008-2009 season.

<http://www.phac-aspc.gc.ca/publicat/ccdr-rmtc/

08pdf/acs-3.pdf $>$ (Version current at August 20, 2008).
2. Allison MA, Daley MF, Crane LA, et al. Influenza vaccine effectiveness in healthy 6 - to 21 -month-old children during the 2003-2004 season. J Pediatr 2006;149:755-62.

3. Englund JA, Walter EB, Fairchok MP, et al. A comparison of 2 influenza vaccine schedules in 6 - to 23 -month-old children. Pediatrics 2005;115:1039-47.

4. Englund JA, Walter EB, Gbadebo A, et al. Immunization with trivalent inactivated influenza vaccine in partially immunized toddlers. Pediatrics 2006;118:e579-85.

5. Walter EB, Neuzil KM, Zhu Y, et al. Influenza vaccine immunogenicity in 6 to 23 -month-old children: Are identical antigens necessary for priming? Pediatrics 2006;118:e570-8.

\section{INFECTIOUS DISEASES AND IMMUNIZATION COMMITTEE}

Members: Drs Robert Bortolussi, IWK Health Centre, Halifax, Nova Scotia (chair); Jane Finlay, Richmond, British Columbia; Dorothy L Moore, The Montreal Children's Hospital, Montreal, Quebec; Joan L Robinson, Edmonton, Alberta; Élisabeth Rousseau-Harsany, Sainte-Justine UHC, Montreal, Quebec (board representative); Lindy M Samson, Children's Hospital of Eastern Ontario, Ottawa, Ontario

Consultant: Dr Noni E MacDonald, IWK Health Centre, Halifax, Nova Scotia

Liaisons: Drs Upton D Allen, The Hospital for Sick Children, Toronto, Ontario (Canadian Pediatric AIDS Research Group); Charles PS Hui, Children's Hospital of Eastern Ontario, Ottawa, Ontario (CPS Liaison to Health Canada, Committee to Advise on Tropical Medicine and Travel); Nicole Le Saux, Children's Hospital of Eastern Ontario, Ottawa, Ontario (Immunization Program, ACTive); Larry Pickering, Elk Grove, Illinois, USA (American Academy of Pediatrics); Marina I Salvadori, Children's Hospital of Western Ontario, London, Ontario (CPS Liaison to Health Canada, National Advisory Committee on Immunization)

Principal author: Dr Marina I Salvadori, Children's Hospital of Western Ontario, London, Ontario

The recommendations in this statement do not indicate an exclusive course of treatment or procedure to be followed. Variations, taking into account individual circumstances, may be appropriate.

All Canadian Paediatric Society position statements/notes are reviewed, revised or retired as needed on a regular basis.

Please consult the "Position Statements" section of the CPS website (www.cps.ca/english/publications/statementsindex.htm) for the current version.

This article also appears in the October 2008 issue of Paediatrics $\mathcal{E}$ Child Health. 


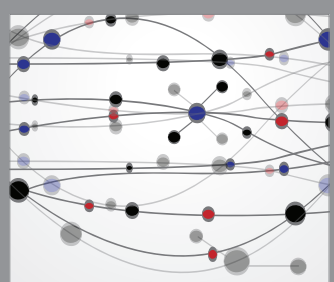

The Scientific World Journal
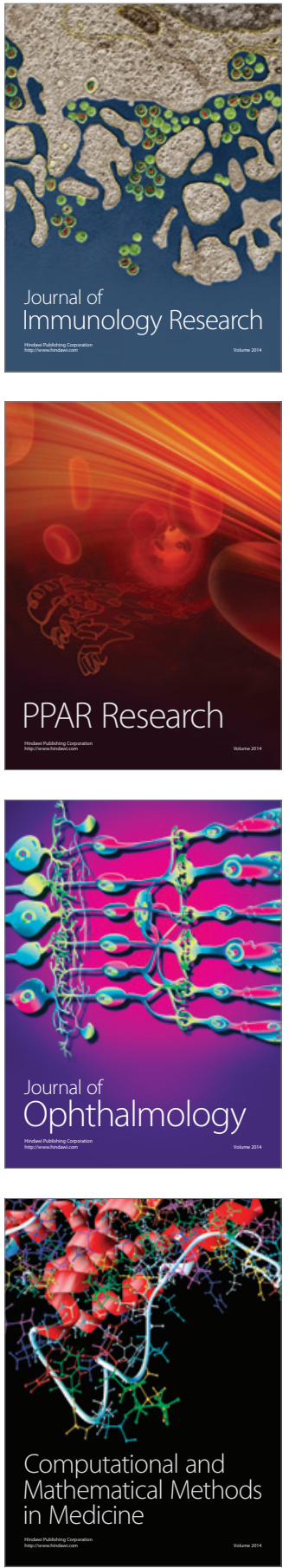

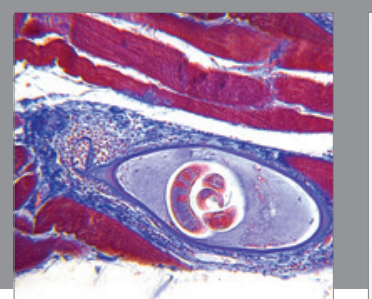

Gastroenterology Research and Practice

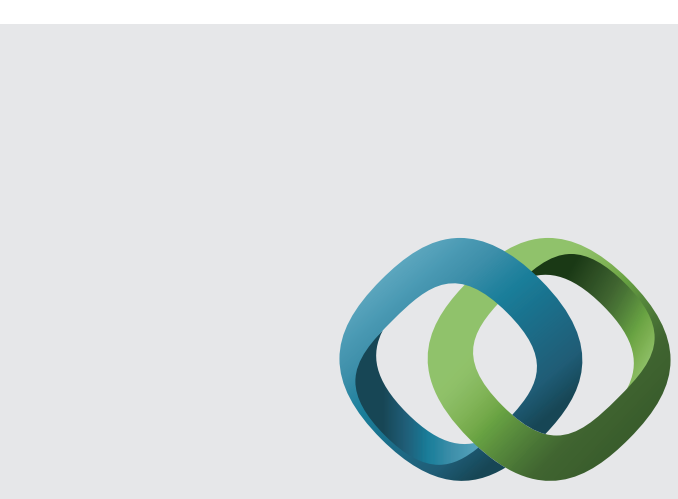

\section{Hindawi}

Submit your manuscripts at

http://www.hindawi.com
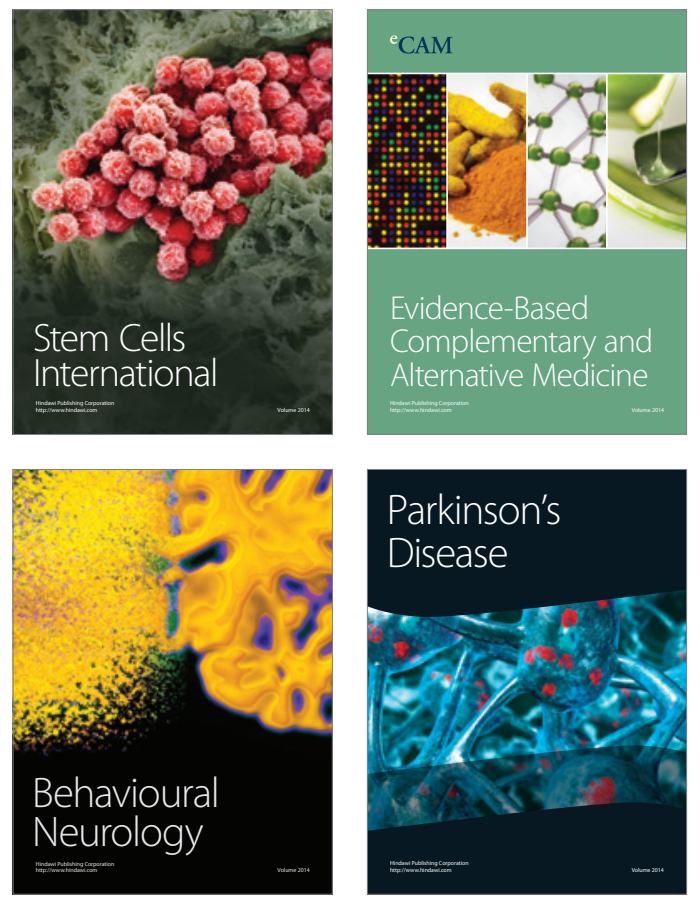
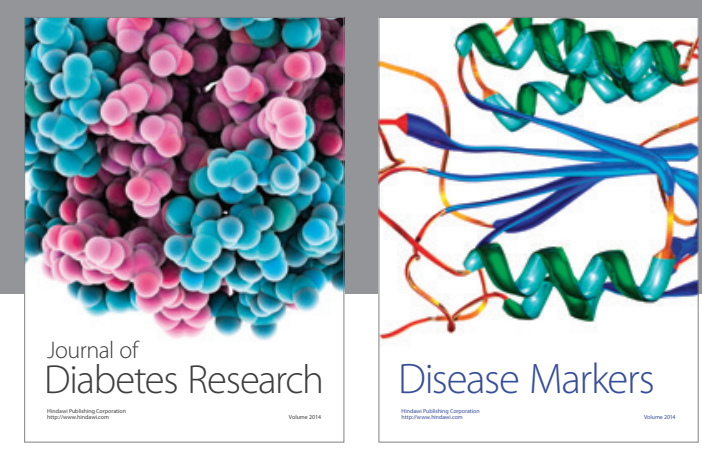

Disease Markers
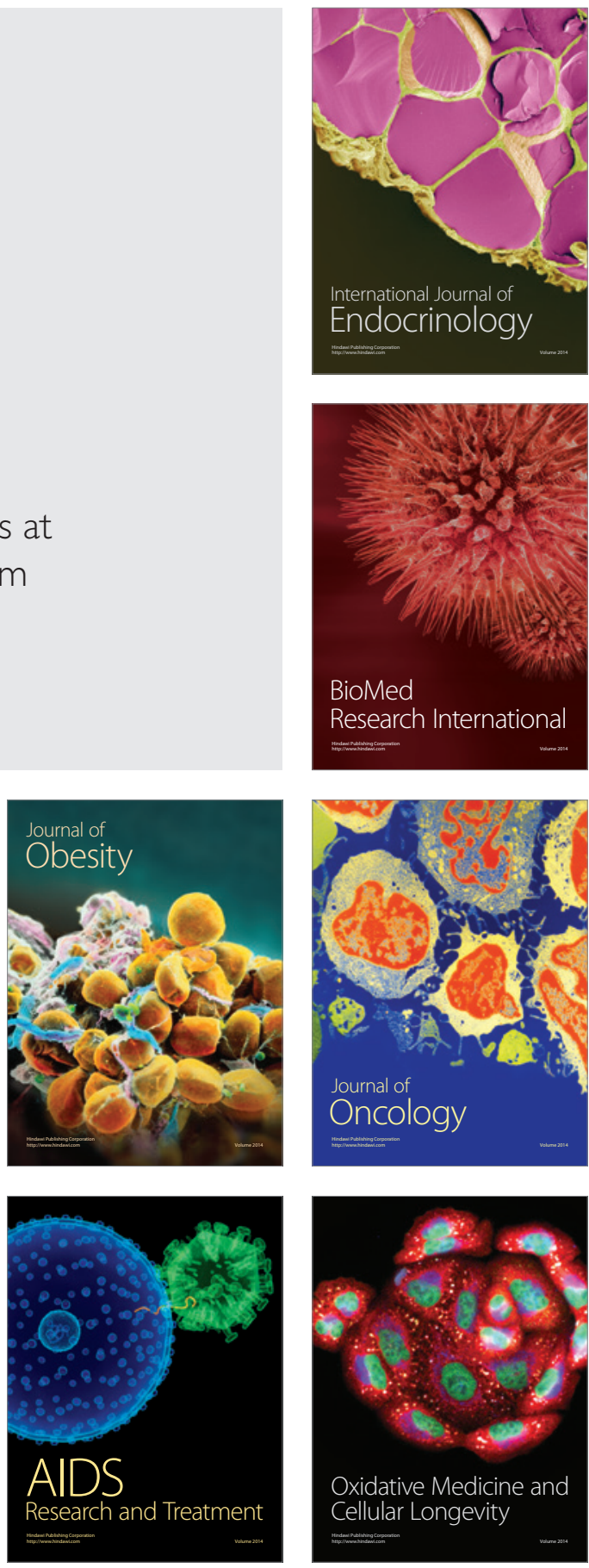